\author{
Aleksy Szymkiewicz \\ ORCID: https://orcid.org/0000-0003-3792-5106 \\ Faculty of Anthropology and Cultural Studies, \\ Adam Mickiewicz Univeristy \\ Poznan, Poland
}

\title{
Identity, place and values. On construction and internalization of festival normalities on the examples of music festivals in Poland
}

\author{
Tożsamość, miejsce i wartości. 0 konstruowaniu i internalizacji \\ festiwalowych normalności na przykładzie festiwali muzycznych \\ w Polsce
}

\begin{abstract}
:
The aim of this paper is to compare of how two different festivals stimulate specific norms and perceptions, and therefore to present the way in which the visions of the festival cities are reproduced by the festival audience based on the axio-normative orders contained in the missions of the events. Based on the shared symbols and life strategies promoted by festivals, participants (re)build their identity which they manifest in chosen cultural practices. The article attempt to answer the following question: what is shared by festival-goers? Are the main motivations for participating in the vent due to shared musical tastes or also specific values and lifestyles, and consequently a common identity? It has been shown that the values promoted during festivals are declared by their organizers - they are present in the visual identification, seminars, workshops, etc. Festivals create their narratives based on symbols such as logos, attitude smartphones, or festival slogans which contain condensed axio-normative systems that create the boundaries of the community. It influences the behavior of festival goers: the city's vision, ways of spending free time, and their identity.

The places where the fieldwork was conducted were: "Henryk Rasiewicz National Festival of Unbreakable and Independent Songs in Kraków", "Ostróda Reggae Festiva" in Ostróda, and the "Song of Our Roots Festival" in Jarosław.
\end{abstract}

Keywords: festivals, identity, life styles, reproduction of place, axio-normativity 
Celem artykułu jest porównanie stymulacji określonych normy i sposobów percepcji dwóch odmiennych festiwali, a tym samym ukazanie metody reprodukcji wizji festiwalowych miast przez festiwalowiczów $\mathrm{w}$ oparciu o aksjonormatywne porządki zawarte $\mathrm{w}$ misjach tych wydarzeń. W oparciu o wspólne symbole i strategie życiowe promowane przez festiwale uczestnicy (re)produkują swoją tożsamość, manifestowaną później w wybranych praktykach kulturowych. Artykuł jest próbą odpowiedzi na następujące pytanie: co łączy festiwalowiczów? Czy głównymi motywacjami do udziału w imprezie są wspólne upodobania muzyczne, czy też specyficzne wartości i style życia, a w następstwie wspólna tożsamość? W artykule wykazano, że organizatorzy festiwali deklarują określone wartości poprzez lokowanie ich w tematach seminariów, treści warsztatów, obecności w identyfikacji wizualnej etc. Festiwalowe narracje konstruowane są w oparciu o symbole takie jak logo, stosunek do smartfonów czy hasła festiwalowe, które w swojej treści zawierają, skondensowane systemy aksjonormatywne, wyznaczające granice wspólnoty. Wszystko to ma istotny wpływ na zachowanie festiwalowiczów: ich wizję miasta, sposoby spędzania wolnego czasu czy tożsamość uczestników.

Miejscem prowadzenia badań terenowych były: „Ogólnopolski Festiwal Piosenki Niezniszczalnej i Niezależnej im. Henryka Rasiewicza” w Krakowie, „Ostróda Reggae Festival” w Ostródzie oraz „Festiwal Pieśń Naszych Korzeni” w Jarosławiu.

Słowa kluczowe: festiwale, tożsamość, style życia, reprodukcja miejsca, aksjonormatywność.

Odebrano / Received: 25.03.2021

Zaakceptowano / Accepted: 05.10.2021

It is impossible to understand culture in isolation from the technology that gives life to it and makes it coherent. The power of the imagination - and thus the hegemony of interpretation - is not possible without control over the circulation of cultural content, i.e. the media. Understood in an anthropological way, the media defines the environment in which our ideas about the world function. (...). That is why the way in which the imagination of a given time relates to the media can tell us a lot about important social changes. Usually it is the "new" media that has been attacked by supporters of old communication technologies. Marcin Napiórkowski, The Power of Imagination, 2014.

It is an early summer evening. We are standing on the historic market square in front of the courtyard of the Orsetti townhouse in the city of Jarosław, which hosts the city museum. The sun is slowly setting to the west, which adds to the mood and colour. Old, uneven cobblestones, black, arched lanterns and the brick wall of the courtyard evoke the undefined history of this place. We are waiting for an impromptu concert. We only found out about it a couple of hours ago. A group of young Italians are waiting, sitting on the stairs and eating pizza straight from the box. Before we enter, we scan the courtyard for our places, soon it will be dark. The only source of light is the sodium lamp at the back of the yard. It illuminates an old iron gate placed in the wall with a warm orange light. A few people who could not participate in the concert due to pandemic 
restrictions ${ }^{1}$ are peering over it, resting their heads on the top. Other lamps and portable light sources either were not working or were simply not there, the same with the loudspeakers. We are sitting on chairs, stones, curbs and a low wall.

A Corsican singer, Jean-Étienne Langianni, is the artist of the moment and is presenting his traditional, national songs with a choir from Vilnius, whilst Julia translates his words between songs into Polish. This intimate concert, which takes place on August 23 2020, opens the "Song of Our Root" festival. Everyone is dressed in black. Their slender figures are only just illuminated by an LED lamp next to the sheet music stand. They are barely visible in the dark. Jean-Étienne emphasises that both the songs and the entire Corsican tradition are still alive. His words contrast with the pop music that comes from a window of one of the flats in a neighbouring townhouse. At one point, he tells a story about how, before the era of television, people met by the fire, in the market square, and told stories, and now they sit alone in their homes. When Julia finishes translating his words, she says that she would like to tell one of her own stories, because it reflects what the artist was talking about. Some time ago, she looked after an old woman in Corsica. Every day she wanted to go out on the balcony, but when there, she mourned that: "Nothing is happening here. It's a city where you can die". Apparently, she saw every detail - people opening the shutters, hanging up the laundry, etc. - her life was about what happened on the street, but was not visible any longer. One day she said that "all of this" was because of TV - "it ruined it all". Julia adds after a pause: "And I think it is the case". The silence in which the tale resounds, blends with laughter and applause. The moment is interrupted once again by the music coming from a nearby flat. Some people comment that the malicious neighbour is trying to disturb the concert in retaliation for the annual festival night fun. "Jarosławians are pure malice!" - adds one of the regular participants of the festival.

This nostalgia for the past world, which was not subject to such rapid changes, combined with the slight decadence and criticism of modernity, seems significant - especially here: in the old market square of Jarosław, during the "Song of Our Roots" festival, where early music is played among people dressed in the colours of the earth, "natural" fabrics or clothing with a mountain-tourist twist. Later, I notice that none of the festival participants were taking pictures with their phones, they rarely telephoned others, but instead wrote text messages. Taking your phone out (let alone flaunting it) was seen as tactless. Curiosity pushes me to try and catch someone using their phone, surreptitiously take a photo to post on some social networking site - but none of this

\footnotetext{
1 During the summer of 2020 in Poland, three local restrictions were introduced depending on the number of residents infected with coronavirus and the country was divided into green, yellow and red zones. The restrictions pertaining to public places changed depending on the number of those infected in a given locality (poviat)
} 
happens. The vast majority of them do not even have such a possibility, because their phones are equipped with keyboards and lack LCD screens on which you can browse Instagram and Facebook. Nobody pulls out their phone while waiting for a concert or workshop. After four days, it looks like an unwritten rule. Only in the evening, with the stories told at the table, do old friends fill each other in with photos that circulate on the few telephones with large screens, showing important moments which they have captured just to show them to others.

Two months earlier, in July 2020, when we were conducting research at the "Ostróda Reggae Festival", no one had any problems with talking on the phone, taking pictures or recording videos and sharing them in real time on the internet. In comparing the two events, the main question I ask myself is: what connects and divides these two patterns of action? How is it related to festivals and the places where they take place? And most of all: is there anything in it that is not accidental?

This article is based on ethnographic field research carried out as part of the project entitled "Festivalisation of values: Axionormative dimensions of contemporary music festivals in Poland". So far, the vast majority of festival research has focused on the division into the sacred and the profane (Durkheim 1961; Mauss 2004), the concept of secular and sacred time (Eliade 1959) or ritual, performance and liminality (Turner 1957, 1969, 1987). Although these works draw attention to "festive forms", a lot of time has passed since their publication. Many things have changed. The previous, traditional festive forms were included in the value systems of the entire community, being part of everyday life. Today, festivals are attended mainly during the summer holidays, chosen willingly from a range of possibilities. Since then there have been festivals like The Woodstock Music and Fair (Bennett 2004) in the United States of America, Woodstock Festival in Poland (Żyła 2017), and for many iconic Jarocin (Kuligowski 2015) which significantly changed the festival life. Today, the sphere of values is declared more explicitly. Festivals openly display their missions. They consist of official "festival missions", organizers' declarations, symbolic gestures, and the behavior of both artists and participants, as well as language and visual codes. They are also experienced differently, they usually happen during the summer holidays and have become part of both global and local tourism. Current perspectives include those touching the problem of the image of place (Bjälesjö 2002; Kozorog 2011; Selberg 2006), spirituality (Gilmore 2010), or present ecological, multi-faced approach (Frost 2016).

Investigating music festivals requires the use of many different research methods. Field ethnography is an essential tool and technique used in the project. The research team consisted of seven people who conducted both interviews (qualitative method) and surveys (quantitative method), but also used participant observation, notes, as well as audio, video and photo recordings. We expanded the research with art-based research techniques, which complement the fieldwork with a specific qualitative element in order to try to capture the subjective experience of research partners through creative artistic 
activities. So far, the research has been carried out during the "Henryk Rasiewicz National Festival of Unbreakable and Independent Songs" in Kraków (in 2019, before the coronavirus pandemic) and in 2020 during the "Ostróda Reggae Festival" (hereinafter: "ORF") in Ostróda and the "Song of Our Roots Festival"(hereinafter: "SORF") in Jarosław (during the coronavirus pandemic) ${ }^{2}$. The materials collected at the latter two constitute the empirical basis of this article.

At this point, it is worth noting that an important tool in my work is the axio-normative theory, which I develop further in the article. It is applied to festival research. As it was mentioned before, the attempt of this paper is to understand music festivals as zones for promoting certain values, observe how these values are internalized, and try to recreate the narrative about modernity, technology, and festival values based on axio-normative orders. Therefore I refer to Florian Znaniecki who wrote about the cultural patterns of social systems that include certain values and norms. For the record, I will mention that the smartphones and TV sets mentioned in the ethnographic description will be understood as manifestations of festival normality, as media filled with festival values and norms.

Values are an important issue not only in the academic world, but also the festival industry is consciously turning its attention to them. Yourope is the European Festival Association founded in 1998 with the purpose of improving the European festival scene and connecting cultures. It has since evolved into the most important association of European popular music festivals. Today it represents 108 festivals and associated members from 26 European countries. On their website, we can find that it was established by dedicated working groups that deal with health and safety (YES Group), sustainability and green operations (GO Group), and social awareness (TAKE A STAND).

All of 2020's festivals and music events were uncertain. Most of them did not take place at all or took place in a restricted, "pandemic" formula, which required compliance with certain sanitary and epidemiological requirements. In Poland, as well as the previously mentioned zoning there was also a restriction on public gatherings. The number of participants at the "Ostróda Reggae Festival" was limited to 999 people (this is how many could enter the city amphitheatre building, where the festival was moved to). As well as this, the event was subject to other minor restrictions, as the city was in the green zone. By contrast, the "Song of Our Roots Festival", which took place in Jarosław, was uncertain until the last moment, as the city was in the red zone (of which we were reminded by street announcements). About 150 people attended the event, while "normally" there would be three or four hundred participants.

2 It is worth noting here the size diversity of festival cities. Cracow is the second most populous city in Poland (less than 800,000 inhabitants). Jarosław, located in the Subcarpathian Voivodeship, has 38,000 inhabitants, while Ostróda in the Warmian-Masurian Voivodeship has 33,000. 
Most of the music events could not take place physically and were therefore transferred to the virtual sphere and kept alive thanks to the internet. Sometimes they took the unique form of events taking place in accordance with the restrictions in force at the time. The situation raised concerns of the organizers (related to organizational problems as well as uncertainty as to the number of visiting participants) and, to a lesser extent, festival-goers (who might have been afraid of an epidemiological threat). After all, a lot of people we spoke to said that the ongoing coronavirus pandemic was a danger, but a greater loss than the disease itself was not to come to the festival, which they have been waiting for the whole year. For the above reasons, the festivals that took place in 2020 were exceptional editions - on the one hand, they were limited by numerous restrictions, on the other hand, they brought together the most die-hard fans who, despite the raging pandemic, decided to come and take part in them.

\section{Two models of experiencing festivals}

We meet participants of both festivals in identical situations - organised despite the pandemic. When we ask festival-goers why they came and whether they were afraid of the coronavirus, we usually get a similar answer:

I had doubts whether it would take place (festival) and whether it made sense to come. I found the risk to be less than the loss of if I wasn't here. And it [the risk] can be reduced with precautionary measures (Jarosław, male, 35);

The virus didn't influence my decision, although something could have happened - I was in quarantine right before. But whether something would happen here (someone would fall sick) was not important to me (Jarosław, female, 33);

I don't think about it (coronavirus). You forget about it in places like this. I think about it every day. Mostly because of my relatives, that I could get sick and infect others (Ostróda, female, 29);

(Coronavirus) is dangerous. We don't know what to do. We are in panic. The fact that it exists is being abused. But I'm not afraid of it here (Ostróda, male, 52); I'm not afraid. I didn't even think for a moment about not coming here. There is a virus, but I don't panic (Ostróda, male, 37) .

The vast majority of people were thirsty for social contact, claiming that they "couldn't imagine not coming to the festival they had been waiting the whole year for" (Jarosław,

3 All materials can be made available upon request. 
female, 31). Therefore, it is possible to say that the festival community of both events expected a meeting of people who shared similar views (as the research conducted during both festivals showed). However, their attitude towards values associated with the smartphone and Internet was utterly different.

In an article entitled Multi-sensory culture of an event Tomasz Szlendak claims that the process of festivalization (of culture) is accompanied by a social compulsion to emit sensations: "Any sensations one experiences should be emitted today, shown, externalised, transferred to the network data reservoir" (Szlendak 2010: 84). This is because there is a lot going on, there is a lot of excitement, but it is temporary and it fades quickly. As Bernadette Quinn writes, festivals become "a public spectacle for outsiders" (Quinn 2009: 19). Festivalisation is an accumulation and intensity of events: workshops, lectures, concerts, shows, etc., which, according to Szlendak, offer experiences, excitement and sensations that are extremely ephemeral. "Experience, excitement, sensation (counted and thrown into the collection of other sensations) have today replaced the old type of spiritual elation that was once experienced in contact with art" (Szlendak 2010: 89). Indeed, the festival in Ostróda is an example of a condensed event. You can experience a concert, wait in line for a grilled sausage or beer, or buy "Nepalese" sirwal trousers, and then soon after be wearing them and swinging along to the music next to a sound system. There are tents with toys, clothes or food on the grass by the promenade. Similarly, during the main concert there are seats for the audience, a separate dancing area and a gastronomic zone where you can buy food, but also meet for a beer or smoke a cigarette. All of this is captured in photos and videos, which then almost immediately are sent to, for example, a Facebook group for the festival goers. The group is a very active one: there are posts almost every day, and members share their excitement of everything revolving around reggae, be it even tangentially.

Experiencing the events of the "Song of Our Roots" festival is different - participants start their day with matins in the collegiate church, which is a liturgy focused on singing in Latin. Soon after there are choir workshops, which last about five hours with a break. After that, everyone participates in masses and vespers, and then, in slightly smarter attire, they go to a concert that takes place in the adjoining church. It is usually experienced as elation, somewhere between sleep and wakefulness. When the concert ends, everyone gathers next to the Siwa Kurka restaurant to organise a spontaneous dance with live music that lasts several hours. Our research group were the only people who recorded these events. In "normal" circumstances (except for the pandemic), photos are taken by a photographer and later displayed on a line strung outside the museum in the Orsetti townhouse, where those interested can choose prints. There is no activity on the Facebook festival group, except for the organiser posting some information from time to time. Even the programme of events is difficult to find, instead it is passed on orally, from participant to participant. 
The reasons for the different experiences of the discussed festivals can be found in various life strategies defined by the community and the festival mission. Both events, like any other cultural event, require cultural competencies that are understood differently. These differences may result from a different distribution of accents both in the sphere of values and norms, as well as their different axio-normative orders.

\section{Two festival missions}

Festival organisers create the festival mission and seem to be the most influential in "designing" the spectrum of participants' experiences. The mission, regardless of how it is "conceived of" (what values it presents), indicates a direction of thinking about the festival, and the perception of concerts, workshops and accompanying events (Getz 2008; Poprawski et al. 2015). It also has an impact on the experience of the city, its spaces, attractions and monuments. The festival's mission includes condensed ideas, goals and visions. The goal of the both festivals is to hit the appropriate audience with their set of values and norms. A specific axio-normative order is internalized by attendants what tight boundaries of community and make it somehow homogeneous. The issue of adapting the festival's mission to the pressure or desires of festival-goers seems interesting also. It is worth to developing as a separate issue in a further research paper. The subject cannot be properly exhausted in this paper due to the page limits.

Given this, it is worth taking a closer look at the organisers' statements. The organiser of the "Ostróda Reggae Festival", when asked if the festival is promoted with specific values in mind, replied:

Sure it is. (...) For example, we don't invite homophobes, and there are lots of them in Jamaican music, who want to burn people with different views, to get rid of them once and for all. We do not tolerate such artists, colloquially speaking - they are banned from performing with us. I understand that maybe the public is waiting for a concert by such artists, but at our festival, which has specific assumptions and a message, such an artist won't find a place here. Certainly, there won't be an artist who will promote, in some way, nationalism, a too extreme nationality, because these phenomena are foreign to us and we do not want to participate in them ${ }^{4}$.

It is clearly visible from this statement that the festival's mission is inclusiveness and aimed at including a wide range of participants with certain values, including: "a message primarily of respect, tolerance, love, mutual acceptance, a smile". When asked about a "typical" festival-goer, the organiser describes two models of participants, although he accepts that there may be more. The first group includes people who identify

\footnotetext{
${ }^{4}$ All statements by the ORF organiser come from interviews conducted remotely (online), during the first wave of the pandemic (March - May) in Poland in 2020.
} 
with the Rastafari movement and live according to its principles (dreadlocks and vegetarianism are among the distinguishing features). The second model is represented by people quite loosely related to reggae music, who come to the festival with their families, children, and for whom the main goal is relaxation and a good time, combined with consumption - eating and drinking. During the conversation, the organiser also notices that there is a permanent group of fans who always appear at the festival regardless of the line-up and circumstances. The organiser estimated that this accounts for about $20-30 \%$ of people, who buy tickets before the line-up is even released. One of the festival's institutions to promote values is the Reggae University, which is defined as a series of events and debates aimed at educating and promoting "respect, tolerance and mutual acceptance".

By contrast, when asked about the key values for the festival, the organiser of the "Songs of Our Roots" replied:

Certainly tradition, because it is impossible not to refer to it. And the community: in singing, in music, in meeting each year. People even talk - without us bringing it up - about the Jarosław family. People who are here, when they meet somewhere in Poland, refer to themselves in this way.

When he talked about his first volunteering experiences during the festival, he emphasised that he immediately "felt part of the community", but also about a different attitude to other music festivals, which is about "a (different) approach to festival guests, less emphasis on the line-up, and more on creating a week filled with workshops and seminars". The seminars are one of the key elements of the festival that is emphasised by the participants. They provide the opportunity to talk with artists and debate together. A few days after the festival, we received a message from the second organiser, in which he wrote that he wanted to add something when it came to looking for an answer to the question of the necessity to address tradition and to develop the topic of the extent to which it is possible to "experience the past". At this point, it is worth paying attention to the characteristic figure of a bee, which is part of the visual identification of the festival, and therefore appears on posters, T-shirts, bags and badges. We heard from the same organiser that:

the bee has been with us from the beginning. It represents us and our guests. We fly around the trunk, the root and try to get inside, to that hive, to grab something and talk about tradition. This is our symbol.

5 The statements come from interviews with the organisers that took place during the SORF festival in 2020. 
On the other hand, another organiser speaks about the image of a bee as follows:

a tree has a root, a trunk, leaves, it symbolises the whole culture, along with tradition, something that is the core of this tradition and something that grows out of it. People are bees who fly around this great tree. Volunteers and organizers identify with these bees.

The above statements clearly show how some characteristic features of both the discussed festivals are parts of totally different missions. The key issue is that both of these contemporary festivals are built on a precise selected message and mission. The purpose of this phenomenon is to promote values and differentiate one festival from another. The "Ostróda Reggae Festival" brings together people who are part of the subculture, but also those who come to the festival to find various attractions, drink beer and eat something together, as well as those who travel to various festivals on the summer season. ORF is a festival promoting specific values - respect, tolerance and mutual acceptance. Among other festivals is distinctive by anti-homophobia statements. In this case, the "Reggae University", aims to promote certain values and attitudes among participants. Reggae music legends, role models and public figures meet there to talk about and debate specific ideas. We can therefore say that ORF reveals a certain axio-normative sphere to festival-goers in order to emphasise its positive values. The "Song of Our Roots", from the other hand, is based on a different axio-normative set. The festival is visited by people for whom tradition, experiencing the past, and the need to extract, search for and talk about them is an essential part of the participants' identity. Although neither the organisers nor the festival goers emphasised this fact too much (perhaps they consider it obvious), religion is also one of the festival's main values. It is the seminars, lectures and debates that form the core of the festival. Music is an addition, a pretext for discussion, an opportunity to start a debate and an opportunity to meet. The festival-goers are a narrow group of people (the average audience is between three and four hundred people), and as the organisers say, the measure of success, is: "when only a fer people come, I would say perversely, because then a community is formed". In view of what has been presented earlier, the festival in Jarosław can be called homogeneous, as it gathers a narrow audience whose identity is based on a specific sphere of values. The goal of the festival's events is to strengthen this sphere, to tighten community ties and create a "Jarosław family". The success of both festivals is the fact that its mission reaches a homogenous group of people that accept, share and identify with a given axio-normative set.

\section{Florian Znaniecki and axio-normative order}

The way in which both groups of festival-goers interact with new technologies says a lot about their axio-normative attitudes. The attitude of the participants of both festivals to modernity and new media, as well as the way of experiencing events, i.e. participation in them directly and also through various media, proves that they accept the 
norms and values defined for a given community. The media, and in this case the attitude towards them, will serve as a starting point for tracing the axio-normative systems of festival goers from Ostróda and Jarosław. The media will not be understood here as a figure mediating access to information, but as a part of the social world, embedded in the network of relations between actors. And above all as forms imposed on festival attendants that materialize a normative sphere of a festival.

Mark Boyle (Boyle 1997) points to the involvement of power dynamics in the organisation of festivals and argues that events are socially constructed in different ways by specific groups to promote particular ideas and beliefs. Both in Festivalization of Culture (Bennett et al. 2014), Getz's review (Getz 2010) and in Kuligowski's work (Kuligowski 2019) we can find claims that one of the essential features of the festivalization of culture is organising festivals to promote and communicate certain moral and ideological values (and for modelling personal image, for example through social media).

In an article entitled Sociometry and Sociology published in 1943, Florian Znaniecki writes:

The cultural pattern of a social system includes certain axiological standards which participants in the system are supposed to apply in evaluation of each other and the system as a whole, as well as certain norms by which they are expected to be guided in their actions. In so far as they accept and conform with these standards and norms, the social system manifests a dynamic inner order which may be termed "axio-normative" (Znaniecki 1943: 225).

This order is revealed in action, and in the case of the Jarosław festival, it is the communication of the participants' relations with technology, modernity, history or decadence. In a book devoted to Znaniecki, Elżbieta Hałas (Hałas 1991: 21) writes about ideological models and calls them "culturally designated ways of experiencing meanings and values". These values and attitudes are internalised through a festival mission that imposes methods of participation in events and activities in the community.

Integration through distinction is an essential property of order for a community. By this I mean the attitude of a given community to other members of society. The axio-normative order appears when selected ideological attitudes are accepted by the greater part of the community, which allows for defining the group's identity, boundaries, norms and standards. In order for individuals to function together, they must communicate and, at least to a minimal extent, share normative knowledge. It is these standards that allow for mutual unity with each other in opposition and relation to others who are outside the sphere of shared attitudes. The attitudes and values in question are manifested in action through various forms of participation. For example, the smartphone mentioned in the ethnographic description at the beginning of the article is understood as representing new media (in this case also television), but also everything that is associated with modernity. A modern lifestyle, rooted out, devoid of tradition, is 
understood by the festival participants in Jarosław as being in some way harmful, causing unfavourable social changes - it is a synonym for individualisation and breaking community ties. As for the festival in Ostróda, I propose the slogan "One Love", repeated regularly by the participants as the equivalent of the telephone. It represents an attitude of openness, respect and tolerance towards the Other, regardless of origin, skin colour or sexual orientation. It follows that the activities undertaken at the festival are value-driven and aimed at regulating social interactions - they are linked according to specific norms and manifest selected ideological attitudes. We can therefore define them as axio-normative, because they introduce these values into the lebenswelt (the world of everyday life).

\section{Festival life strategies}

As has already been established, the festivalization of culture is about treating events as a medium to promote certain moral and ideological values (Bennett et al.2014; Getz 2010; Kuligowski 2019). Another key factor in this process is understanding music festivals as places of coming together, where activities are aimed at maintaining relationships within the community. The place itself is understood in this case as the background for shaping a personal image (Bennett et al.2014; Getz 2010) and it is therefore worth looking at these festivals from the perspective of the concept of lifestyle.

In one of his most important works entitled Modernity and Self-Identity (Giddens 1991) Anthony Giddens presents the concept of "lifestyle" as a necessary and fundamental feature of late modernity. Life strategy $y^{6}$ today is "adopted", chosen from a range of others, and not inherited from ancestors along with their pedigree, which, according to the author, was supposed to have taken place "earlier", in the "pre-modern" era. A lifestyle, according to Giddens, "can be defined as a more or less integrated set of practices which an individual embraces, not only because such practices fulfil utilitarian needs, but because they give material form to a particular narrative of self-identity" (Giddens 1991: 81). These practices are eating habits, ways of speaking and dressing, habits of meeting in certain spaces, and as Giddens notes, they are not about what to do, but who to be. Referring to values and norms, life strategies are an imaginary set of traits to which one can aspire. We share them with the community with which we identify. In other words, like shared values and norms, life strategies allow for a feeling of belonging to a group.

In their volume already cited above, Andy Bennett, Jodie Taylor and Ian Woodward (Bennet et al.2014: 14) write: "Festivals therefore produce a temporal, yet highly visible and in some cases inherently spectacular, display of commonly shared lifestyle preferences". We will not find homophobes or nationalist content at the festival in Ostróda. Similarly, at the festival in Jarosław, some content will be valorised as inappropriate or received unfavourably. Although the participants we interviewed declared that

${ }^{6}$ Used interchangeably for "lifestyle" due to problems with excessive popularity of this term. 
non-believers could also participate in the festival, they belonged to a definite minority (I personally met only one person who described himself as a non-believer). We, too, as social and/or humanities researchers, heard from one of the leading artists (often cited as an authority) that "modern humanities are useless and introduce unnecessary relativism that could be avoided by using medieval thinkers". Referring to the boundaries of a community, the certain norms that create it (an order) allow for defining collective and individual identity (Barth 1969; Getz 2010; Znaniecki 2001). According to Znaniecki, this order is manifested in the decisions taken. In my opinion, we can understand these decisions as choices of life strategies that (re)construct our collective and individual identity.

The festival's "missions" promise to fill the ideological space, the axio-normative sphere, by making choices of life strategies, as it were, for the festival goers. It is on the basis of these spheres that festivals create their narratives, which organise the festival community - and thanks to which, one can speak of a "Jarosław family". Activities expressing and externalising strategies and orders allow for the creation of a temporary "dream reality" that promises specific visions of freedom (participants feel free during the festivals they identify themselves with) or social reality - as one of the participants of the "Ostróda Reggae Festival" told me: "Ostróda should last 350 days, and the remaining five should be normal life". This sense of freedom can be considered as universal for music festivals:

With regard to festivals, it is therefore possible to identify a process whereby the freedom to choose, via careful segmentation, from a range of distinct festival brands with correspondingly distinct, tailored and preferred (niche) experiences is simultaneously accompanied and enabled by drawing on an over-arching mythology of festivals that promises its own set of freedoms and opportunities, including - among other things - freedom from 'everyday structures and systems'; the possibilities of hedonism and excessive consumption; authentic connections with others; and alternative expressions of identity and identity-formation (Morey et al. 2014: 253-254).

If attendants have any needs, the organizers meet them. Our participants, when asked what they would change in festivals and whether they need something more, usually did not answer this question. During the events, participants have the opportunity to buy not only festival gadgets but also books, clothing, and music CDs. In Ostróda, there were marketplaces with clothing from Nepal, toys for children, in Jarosław, in turn, a stand with books on religious topics and early music. Following this lead, ORF organized sound systems at pier, and SORF evening dances to early music.

At this point, it is worth noting that the identity of the participants is probably already formed before they encounter the festival - in spite of all, participants voluntarily choose the festival they wish to go to. However, what is happening during these 
events is (re)creation and confirmation of the identity of the participants. What allows these activities and strengthens them at the same time is the mission of the festival, which contains a complete set of information about the values and norms of the festival. Therefore, we can say that the essential experience expected by the audience of the festival is authenticity - the authenticity of values, norms and emotions with which they will be able to identify with. Festivals give their participants the freedom of choice and expression, which strengthens ties with other group members and with the event. These feelings also have a significant impact on the way in which the festival space is constructed and imagined by the festival goers.

\section{Reproduction of places: two visions of the city}

The festival missions, present in the narratives, together with the "sets" of values and life strategies embedded in them, both create and strengthen the existing visions of cities and spaces in which they take place. Festivals offer the sought-after "authenticity" of an experience, as first noted by Dean MacCannell (MacCannell 1976). Quinn describes these great musical events as "a vehicle for expressing the close relationship between identity and place" (Quinn 2009: 22). Festivalisation is both a tool for the promotion of individual places or regions, and a way to create a cultural or historical policy of a place (Bennett et al. 2014; Derret 2003; Getz 2010; Kuligowski 2019). Waldemar Cudny observes that "an extremely important function of festivals and other cultural events is to create the image of the host cities. Festivals create the brand of a given location, which may have the characteristics of a product's brand" (Cudny 2016: 88). In turn, according to Selberg, one of the main goals of modern festivals is "to signify that the location where they take place are unique in a globalized world” (Selberg 2006: 299).

Participants internalize not only the values contained in the festival's mission but also the image of the place that is proposed to them. Festivals construct the spaces in which they take place, creating places that become festival cities in the imagination of festival-goers - this is achieved through promotional material, media image, and narratives; the type of music, the design of the festival venue, or substantial values are also important. This is noteworthy because so far issues related to the impact of the festival's popularity on local residents or place-branding have been discussed (Cudny 2016; Kozorog 2011; Selberg 2006).

What image of the festival venues emerge from the stories told by the organisers and participants? I consider this issue important because it can reveal a lot about how the festival is conceived of and imagined, how it exists in the imagination, and thus it tells us a lot about the narratives about the festival's "missions", axio-normative promises and life strategies. The ontology of the authenticity of this image seems to be equally interesting and important (Frost 2016, Getz 2008). Unfortunately, due to size restrictions, there is no space to cover this here, I would nonetheless like to note that the main objects of my reflection are the experiences of festival-goers - how the place is perceived 
by them, and not whether this image is "real" 7 I am inclined to support the thesis that the vision of a place is the result of festival, tourism and marketing reinvention.

It is significant that both the festival in Ostróda and in Jarosław promote the city or region. Both have a positive view of the festival's locations, describing the city very often as "beautiful" and suitable for tourists. Likewise, with both festivals, the city is associated with the event and the name of the place was used interchangeably with the name of the festival. Despite these surface similarities however, the perception of both locations is different and depends on the axio-normative sphere and characteristics of both festivals.

For ORF participants, the city and the region are seen as attractive places for visitors. Participants associate the festival more with a place of relaxation where you can eat, drink and go to a concert. The city is identified with the festival, and temporary restrictions (for example with regard to drinking alcohol in public places) are lifted, an element emphasised by festival goers. Participants also appreciate the goodwill of the police and the inhabitants of Ostróda. During "normal" (non-pandemic) editions parents can leave their children in designated zones under the care of appropriate staff and take advantage of festival attractions, and it is a popular option according to the organiser. Many people use the festival as an excuse to go hiking and explore the Warmia-Masuria region, while some perceive the event as an opportunity to go camping. For the participants of the SORF festival, Jarosław, on the other hand, is a city rich in history and outstanding architecture. This is interesting because both Jarosław and Ostróda received city rights in the 1420s. Festival-goers often emphasised the fact that the city used to be located at the intersection of trade routes (from Silesia to Ruthenia and from Gdańsk to Hungary), which made it a city of merchants and fairs in the past. One of the participants said during an interview that "events during the festival happen in places along the trade route". We also heard that "the festival brings back the origins and reminds us of history", and "immersion in early music makes me focus more on the tradition of the place where it is made" - this sensory stimulation is also important, referring the participants to the specific ideas of the festival venues. The rhythm of the day, which was imposed by the organisers of both festivals is also an important aspect that is worth pointing out. At the festival in Ostróda, a concert is the main attraction of the day, and, while waiting for it, festival-goers can fill the time with various activities, such as: workshops, sound systems, talks or shared meals. The possibilities of spending time are mainly based on searching for activity and hanging around. On the other hand, the festival in Jarosław has a strictly defined (almost monastic) rhythm of the day determined by masses, workshops, seminars and evening concerts. This division is respected by a majority of

7 To a small extent, we can trace the discussion about the "nature" of the image in an article by Bernadette Quinn (Quinn 2009). 
participants and, according to their statements, seems to be an important factor in achieving spiritual elation.

Both festival cities are perceived by participants in fundamentally different ways. On the one hand, we have Ostróda, which is seen by festival-goers as a centre of local tourism, rich in attractions. The city is perceived as a place of rest and recreation. On the other hand, we have Jarosław, perceived by the "Song of Our Roots" regulars as a former trade and merchant centre and a place steeped in history. They perceive the place and region as rich in tradition, culture and history that they can "discover" through music and participation in the festival.

\section{Conclusions}

In light of the above, can we say that smartphones offer us a hidden narrative about the "Song of Our Roots" festival in Jarosław, its space and life strategies? For its participants, tradition is the axis of identity and the backbone of the story that they tell during the annual event, while smartphones are a symbol of the unfavourable changes that have come along with modernity. Their story is about the search for this identity among the walls of the old city, churches, basilicas and the monastery, where some of the participants sleep. While the phones were only a starting point, they told us much more about the nature of the festival events and community than we could have expected, and the TV story Julia told during Jean-Étienne Langianni's concert was by no means accidental.

As has been shown, music festivals have their "mission", which, in a condensed form, contains both a specific axio-normative order and selected life strategies. They are the basis on which the festival community builds its own identity and can contrast with others. The symbols of the festival missions, in which certain orders are inscribed, are manifested in the activities and strategies chosen. In order for festival communities to coexist and participate in events, it is necessary to share knowledge, values and norms, thanks to which they will be able to make decisions and practice. Participants of certain festivals not only share tastes in music and clothing, but also specific values and lifestyle, and as a consequence, even to some extent, identity. In both cases, we can see that the festivals' values are clearly specified by the organisers. They can be found in visual identification, narratives about the city and space, ways of spending time or workshops, seminars and discussions. Festival-goers share them and identify with them, thanks to which they strongly associate with symbols, space and call themselves "family".

Of course, not all the relevant issues could be addressed. I think it is the manner in which values and norms are manifested in this process, as well as the role of festival authorities, is worth examining. Links between festivals and city/local authorities that influence the image of the region and local tourism are also an interesting issue. This list could be also expanded by the concept of "empathic communities", which may turn out to be extremely important and fertile, especially in the context of music, which, after all, also serves to evoke emotions. 


\section{References}

Barth F. (ed). 1969. Ethnic groups and boundaries. The social organization of culture difference. Oslo: Universitetsforlaget

Bennett A. (ed). 2004. Remembering Woodstock. Burlington, Ashgate.

Bennett A. Taylor J. and Woodward I. (eds.). 2014. The Festivalization of Culture. Farnham: Ashgate.

Bjälesjö J. 2002. The Place in Music and Music in Place. Ethnologia Scandinavica 32, 20-33.

Boyle M. 1997. Civic Boosterism in the Politics of Local Economic Development - 'institutional positions' and 'strategic orientations' in the Consumption of Hallmark Events. Environment and Planning A 29 (11), 19975-1997. https://doi.org/10.1068/a291975.

Cudny W. 2016. Festivalisation of Urban Spaces. Switzerland: Springer Geography.

Derret R. 2003. Making Sense of How Festivals Demonstrate a Community's Sense of Place. Event Management 8 (1), 49-58.

Durkheim É. 1961. The Elementary Forms of the Religious Life, New York: Collier Books.

Eliade M. 1959. The sacred and the profane. The nature of religion, New York: Harcourt, Brace \& World.

Frost N. 2016. Antropology and Festivals: Festival Ecologies. Ethnos 81(4), 569-583.

Getz D. 2008. Event tourism: Definition, evolution, and research. Tourism Management 29, 403-428.

Getz D. 2010. The nature and scope of festival studies. International Journal of Event Management Research 5 (1), 1-47.

Giddens A. 1991. The modernity and Self-Identity: Self and Societu in the Late Modern Age. Cambridge: Polity Press.

Gilmore L. 2010. Theater in a Crowded Fire. Ritual and Spirituality at Burning Man. Berkeley; Los Angeles; London: University of California Press.

Hałas E. 1991. Znaczenia i wartości spoteczne. O socjologii Floriana Znanieckiego. Lublin: Redakcja Wydawnictwa Katolickiego Uniwersytetu Lubelskiego Jana Pawła II.

Kozorog M. 2011. Festival Tourism and Production of Loality in a Small Slovenian Town. Journal of Tourism and Cultural Change 9(4), 298-319.

Kuligowski W. 2015. Sentymentalizacja, topofilia i pokoleniowość. Jarocin re-study. Czas Kultury, 4 (31), 32-42.

Kuligowski W.2019. «They sold the festival out!». Axionormativity as a Future of Festivals. [In:] Mazierska, E. Gillon, L. Rigg, T. (eds.) Popular Music in the Post-Digital Age. Politics, Economy, Culture and Technology. New York-Oxford-New Dehli-Sydney: Bloomsbury Academic, 93-110. https://doi.org/10.5040/9781501338403.

MacCannell D. 1976. The Tourist: a New Theory of the Leisure Class. New York: Schoken Books.

Mauss M. 2004. Seasonal Variations of the Eskimo: A Study in Social Morphology. Routledge: London \& New York.

Morey Y. Bengry-Howell A. Griffin Ch. Szmigin I. and Riley S. 2014. Festivals 2.0: Consuming, Producing and Participating in the Extended Festival Experience. [In:] A. Bennett,J. Taylor and I. Woodward (eds.) The Festivalization of Culture. Farnham: Ashgate, 251-258. 
Poprawski M., Firych P., Landsberg P., Kieliszewski P., Mękarski M., Jakubowska A., Brodniewicz M., Kędzierska R., Kłosiewicz E., Michalczuk J., Zielińska K., Gorgoń J., Węglarska K. i Wróblewski F. 2015. Oddziatywanie festiwali na polskie miasta. Studium kompetencji kadr sektora kultury oraz synergii międzysektorowe. Raport z projektu badawczego. Poznań: Związek Miast Polskich.

Quinn B. 2009. Festivals, events, and tourism. [In:] Jamal T. and M. Robinson (eds.) The Sage Handbook of Tourism Studies. London: Sage, 483-503.

Selberg T. 2006. Festivals as Celebrations of Place in Modern Society: Two Examples from Norway. Folklore 117(3): 297-312.

Szlendak T. 2010. Wielozmysłowa kultura iwentu. Skąd się wzięła, czym się objawia i jak w jej ramach oceniać dobra kultury? Kultura Wspótczesna 4 (66), 80-97.

Turner V. 1957. Schism and continuity in an African society. Manchester: University Press.

Turner V.1969. The ritual process: Structure and anti-structure. Chicago: Aldine Pub.

Turner V. 1987. The Anthropology of Performance. New York: PAJ Publications.

Znaniecki F. 1943. Sociometry and Sociology. Sociometry 5 (3), 225-233.

Znaniecki F. 2001. Ludzie teraźniejsi a cywilizacja przysztości. Warszawa: Wydawnictwo Naukowe PWN.

Żyła M. 2017. Przystanek Woodstock XXI wieku, czyli teatralizacja społeczeństwa i zmierzch kultur. Świat i Stowo, 2 (29), 133-145.

Author:

MA Aleksy Szymkiewicz, PhD Student

Doctroal School in the Humanities

Collegium Maius

ul. Fredry 10, 60-701 Poznań

e-mail: aleksy.szymkiewcz@amu.edu.pl 